\title{
Effect of natural populations of burrowing thalassinidean shrimp on sediment irrigation, benthic metabolism, nutrient fluxes and denitrification
}

\author{
Arthur P. Webb*, Bradley D. Eyre \\ Centre for Coastal Biogeochemistry - School of Environmental Science and Management, Southern Cross University, \\ PO Box 157, Lismore 2480, New South Wales, Australia
}

\begin{abstract}
The aim of this study was to determine the effect of burrowing by natural populations of Trypaea australiensis on benthic metabolism, nutrient flux, denitrification and irrigation rates using in situ benthic chambers and exclusion nets to minimise disturbance and associated artefacts. The burrows of $T$. australiensis enhanced total sediment porewater exchange rates 5-fold compared to uninhabited sediments. Calculated single-burrow flow rates were $<0.4561 \mathrm{~h}^{-1}$, and active burrow irrigation appeared to be linked to tidal movement; as such, ex situ studies (i.e. mesocosm or laboratory incubations) may underestimate burrow irrigation rates. The presence of $T$. australiensis increased sediment oxygen demand by $81 \%$ as compared to unoccupied sediments. Approximately $15 \%$ of this additional consumption was used by $T$. australiensis for respiration, with the remaining $85 \%$ consumed within the burrows by oxidation reactions and microbial respiration. The proportion of smaller sediment particles, porosity and organic matter content was increased in the presence of $T$. australiensis, and sediment surface chl a concentrations were ca. $50 \%$ lower than uninhabited sediments. Net denitrification rates were 4 times greater in the presence of active $T$. australiensis burrows and at densities of 22 burrows $\mathrm{m}^{-2}$ were responsible for approximately $76 \%$ of total denitrification in the study site sediments. $\mathrm{NH}_{4}{ }^{+}$efflux was higher in the inhabited sediments and $\mathrm{NO}_{3}{ }^{-}$and $\mathrm{NO}_{2}{ }^{-}$effluxes were lower, suggesting that increased $\mathrm{NH}_{4}{ }^{+}$mineralisation may have enhanced denitrification via the close coupling of nitrification-denitrification in the inhabited sediments. As such, T. australiensis appears to contribute significantly to net sediment $\mathrm{N}_{2}$ efflux in lower subtropical estuarine environments.
\end{abstract}

KEY WORDS: Bioturbation · Denitrification · Irrigation · Burrowing macrofauna · Sediment biogeochemistry $\cdot$ Trypaea australiensis

Resale or republication not permitted without written consent of the publisher

\section{INTRODUCTION}

Sediment biogeochemical processes play an important role in the metabolism and nutrient cycling of shallow coastal ecosystems (Santschi et al. 1990, Valiela 1995, Jickells \& Rae 1997, Malcolm \& Sivyer 1997). The activity of burrowing infauna within sediments influences these processes by enhancing redox reactions and solute transport, contributing to system metabolism, and by physical reworking (Aller 1988, Kristensen et al. 1991, Pelegri \& Blackburn 1994, Harris et al. 1996). Trypaea australiensis, a thalassinidean decapod shrimp (formally Callianassa australiensis and commonly known as 'marine yabby' or 'ghost nipper'), is an abundant macrofaunal component of shallow and intertidal sand flats in east Australian estuaries, extending from north Queensland to Port Philip Bay, Victoria. T. australiensis burrows often dominate the substrate, with densities ranging from 60 to $>200 \mathrm{~m}^{-2}$ (Kenway 1981, Paterson \& Thorne 1993, Kerr 2001).

The burrow of Trypaea australiensis is reported as being a U-shaped respiratory loop within the upper 30 to $40 \mathrm{~cm}$ of sediment. Descending from a wider turning chamber at the bottom of the loop is a multi-branched network, often over $1 \mathrm{~m}$ deep (Kenway 1981, Kerr 
2001). In situ polyester resin casts of adult T. australiensis burrows have an average total length of 85 to $120 \mathrm{~cm}$, with a typical burrow diameter of $12 \mathrm{~mm}$ (Kenway 1981). These dimensions imply an average burrow surface area of 320 to $452 \mathrm{~cm}^{2}$ (mean $386 \mathrm{~cm}^{2}$ ). Multiplying the mean surface area by reported $T$. australiensis densities (60 to $200 \mathrm{~m}^{-2}$ ) gives a surface area increase of 2.32 to $7.72 \mathrm{~m}^{2}$ per square metre of substratum (or a 232 to $772 \%$ substratum surface area increase).

Trypaea australiensis is a specialised burrowing organism and once settled remains permanently within the same burrow (Kenway 1981, Paterson \& Thorne 1993, 1995). It is a predominantly sedimentsorting detritivore, which may also alternate to filterfeeding habits (Kerr 2001), and is considerably more tolerant of extended periods of anoxia in comparison to other thalassinideans (Paterson \& Thorne 1993, 1995). T. australiensis has complex burrow-working habits, including the sorting and smoothing of burrow linings using fine sediment $(>250 \mu \mathrm{m})$, detrital material and sediment-binding mucus excretions (Kenway 1981, Kerr 2001). These sediment-binding techniques also include the production burrow plugs with which they periodically 'cap' their burrow entrance (Kerr 2001). T. australiensis is also an important pioneer species, being one of the few macroinvertibrates remaining and surviving in estuarine sediments following freshwater flushing events (Kerr and Corfield 1998). Adult T. australiensis are not thought to be predated heavily (as a result of their deep burrows and shy habits); however, they are a favoured bait source for recreational and commercial anglers, and are subject to intense, mostly unmonitored harvesting in intertidal areas.

As a result of sediment foraging and sorting (reactivation of buried detrital material), and the consequential production of faecal matter, Trypaea australiensis enrich the sediments immediately adjacent to their burrow walls and openings with organic matter (Kerr 2001). Other infauna burrow studies (e.g. Branch \& Pringle 1987, Aller 1988, Henriksen \& Kemp 1988, Bird et al. 1999, Kristensen 2000) have shown that organic matter-enriched burrow linings which are subject to regular irrigation (oxidation) may greatly enhance sediment solute flux and $\mathrm{O}_{2}$-dependent processes, such as ammonification, nitrification and respiration. Alternately, pauses in burrow irrigation by T. australiensis, possibly due to episodes of burrow capping or during low tide, quickly results in depleted dissolved oxygen concentrations within the burrow (Paterson \& Thorne 1995, Kerr 2001). The reported tolerance of $T$. australiensis to anoxic conditions (Paterson \& Thorne 1995) may allow enhanced closecoupling of oxic/anoxic conditions within their burrows, and studies of other macrofauna species show that these conditions, combined with typically elevated nutrient concentrations found in infaunal burrows (e.g. $\mathrm{NO}_{3}{ }^{-}, \mathrm{NH}_{4}{ }^{+}$), result in increased rates of sediment nitrification-denitrification (Koike \& Mukai 1983, Aller 1988, Clavero et al. 1992, Banta et al. 1999, Mortimer et al. 1999, Botto \& Iribarne 2000, Kristensen 2000). T. australiensis faecal material and burrow linings are up to 30 times richer in organic carbon than the surrounding bulk sediment, and this material and linings are associated with high densities of bacteria, diatoms and meiofauna (Kerr 2001). Studies of other macrofauna species have also shown infaunal faecal pellets and burrow linings to be micro-niches with large bacterial assemblages, resulting in high rates of mineralisation and coupled nitrification-denitrification (Henriksen \& Kemp 1988, Kristensen 2000). In addition, burrows may also provide a dark habitat for nitrifying bacteria which are light-intolerant (Olson 1981).

Trypaea australiensis irrigate their burrows more vigorously with the onset of water-level increase and may assume a filter-feeding pose whilst undertaking this activity (Kerr 2001). Filter feeding contributes significantly to the organic matter content of the burrow by removing organic detritus, diatoms, plant fragments, etc. from the water column (Kenway 1981, Kerr 2001). Specific burrow-irrigation rates for $T$. australiensis are not well quantified; however, studies of similar species have measured mean burrow flow rates of $149.5 \pm 35.5$ and $139.7 \pm 35.5 \mathrm{ml} \mathrm{h}^{-1}$ for Upogebia deltaura and $U$. stellata respectively (Astall et al. 1997), $50.3 \pm 33.6$ and $96.3 \pm 37.1 \mathrm{ml} \mathrm{h}^{-1}$ for Callianassa subterranea and Jaxea nocturna respectively (Nickell 1992) and 29 to 63 and 14 to $33 \mathrm{ml} \mathrm{h}^{-1}$ for C. japonica and $U$. major respectively (Koike \& Mukai 1983). Considering the tolerance of $T$. australiensis to anoxic conditions and their predominantly detrital feeding mode, their irrigation rates were expected to be at the lower end of this range.

Laboratory and field studies investigating the influence of Trypaea australiensis on sediment biogeochemistry have concentrated on defining respiration, physiology, sediment working, ecology and metabolism (e.g. Kenway 1981, Paterson \& Thorne 1993, 1995, Dittman 1996, Kerr 2001). Considering their wide distribution, extensive sediment burrowing habits, tolerance to adverse conditions and the effects that burrows of other macrofauna have been shown to have over solute fluxes and nutrient cycling (e.g. Aller 1988, Kristensen et al. 1991, Pelegri \& Blackburn 1994, Harris et al. 1996), T. australiensis is likely to have a significant effect on sediment biogeochemistry in shallow east Australian coastal systems.

Despite the apparent robust nature of Trypaea australiensis, this species has shown evidence of stress in response to handling (Paterson \& Thorne 1995, Kerr 2001), and may not behave normally during laboratory 
experiments. The time taken to construct a mature burrow is unknown; however, studies of Callianassa subterranea (a close, temperate-climate, northern hemisphere relative of similar size and burrowing habits) suggest an adult individual may take over 12 mo to establish a mature burrow network (Forster \& Graf 1995). Considering their 2 yr life span (Hailstone \& Stephenson 1961) and the intricate and extensive nature of their burrow working, $T$. australiensis may also take a considerable period to produce a mature burrow system. The time frame, aquarium size and tidal flushing regimes necessary to reproduce in situ conditions limit the use of laboratory experiments. This study aimed to determine the effect of natural populations of $T$. australiensis on benthic metabolism, nutrient flux, denitrification and irrigation rates using in situ benthic chambers and exclusion nets to minimise disturbance and associated artefacts.

\section{MATERIALS AND METHODS}

Study site. The study was conducted within a sheltered subtropical eastern Australian embayment (Readings Bay, Brunswick River Estuary; Fig. 1). The climate is mild, with an average temperature range of 12 to $27^{\circ} \mathrm{C}$ and annual mean rainfall of $1609 \mathrm{~mm}$. Conditions are dominated by a sub-tropical high-pressure belt during winter (June to October), which is associated with stable, clear, dry conditions. In contrast, the summer (November to May) weather is influenced by monsoonal trade winds, bringing heavy rainfall, which subjects the estuary to intense short periods of freshwater flushing (Eyre et al. 1997). Otherwise, the bay remains marine dominated (being ca. $1 \mathrm{~km}$ from the estuary entrance), with salinity ranging from 33 to $36 \%$ during the study period (September 2001). The tidal amplitude within the bay ranges from ca. 0.8 to $1.8 \mathrm{~m}$ during the neap spring cycle. The embayment is shallow, with over $70 \%$ of the area exposed during spring-low tide. Sediments are well-sorted quartz sands (63 to $250 \mu \mathrm{m})$ and seagrass Zostera capricorni meadows are common in all deeper channels. The bay is fringed by dense mangrove stands (predominantly Avicennia marina), which are associated with finer silt $(<63 \mu \mathrm{m})$. Readings Bay is the site of intense productivity and bioturbation, and is used as a feeding/nursery area for a range of resident and transient marine and estuarine fish and bird species. Likewise, Trypaea australiensis was found throughout the intertidal and subtidal sediments, with an average individual burrow density of $51 \mathrm{~m}^{-2}$.

In this study, the modified sediments within the Trypaea australiensis exclusion nets are termed 'treatment' (i.e. $=T$. australiensis removed) and the undisturbed sediments containing natural populations of $T$. australiensis are termed 'control' (i.e. $=T$. australiensis present). The term meiofauna is used here to describe all smaller infaunal invertebrates capable of free movement through the $1.5 \mathrm{~mm}$ square mesh used for the exclusion nets.

Experimental design. Forty days prior to undertaking the treatment and control incubations, 2 subtidal sites were selected. The area of Sites 1 and 2 was ca. $25 \mathrm{~m}^{2}$, and the 2 were separated by a linear distance of $27 \mathrm{~m}$ (Fig. 1). The sites were selected specifically due to the inherent homogeneity of the physical environment, as evidenced by the density of active Trypaea australiensis burrows $\left(22 \mathrm{~m}^{-2}\right)$, the depth $(1.5 \mathrm{~m}$ below ASL [average sea level]), light and tidal flushing regimes, the proximity to seagrass meadows and mangrove stands, and the shoreline. All these factors were identical, as were the frequency and density of ripple and other biogenic structures such as ray wallows. Site 1 (treatment) was prepared as a T. australiensis exclusion area and Site 2 (control) was simply marked for later use.

The exclusion plot (Site 1) preparation was designed to produce the minimum impact possible on infaunal species (other than Trypaea australiensis). A plywood square box (open at the top and bottom) was first pushed into the subtidal sediment to ca. $275 \mathrm{~mm}$ depth.

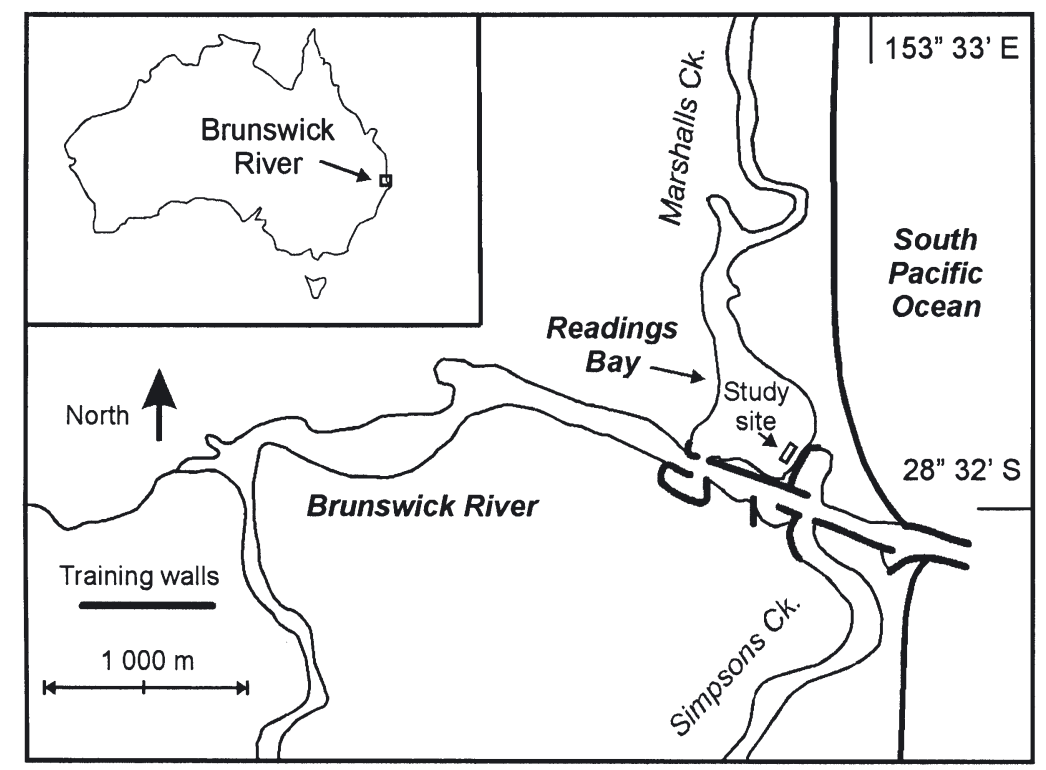

Fig. 1. Location map of Readings Bay, Brunswick River Estuary, and detail of the area used during this study 
The upper $50 \mathrm{~mm}$ of sediments was first removed (very slowly by hand) and retained separately. Subsequent layers (approximately $50 \mathrm{~mm}$ thick) down to 250-300 mm were similarly removed and retained. This left a square hole $(500 \times 500 \mathrm{~mm})$ within the plywood box ca. $275 \mathrm{~mm}$ deep. Into this, a flexible mesh (1.5 mm square) open-topped bag of the same dimensions as the plywood box was inserted, and the respective layers of sediment were replaced as evenly as possible (by hand) back into the mesh bag. Once the backfilling was complete, the plywood box was gently extracted leaving the mesh bag in place. This process was repeated 5 times within Site 1, each exclusion net taking between 35 and 45 min to complete. Earlier trials showed that the disturbance caused by working these sediments caused $T$. australiensis to migrate deep into their borrows, which avoided the problem of contaminating the exclusion nets during backfilling. During these preliminary trials, nets left in the field for 2 mo showed little recruitment via the water column (over the top edge of the nets), with only 1 of 4 nets having a single small $T$. australiensis burrow. No other macrofaunal species besides $T$. australiensis was detected during the exclusion-net preparation in either the pilot or the study.

Productivity and material flux measurement. Benthic incubations were taken over 3 consecutive days during spring (September 2001). Four pre-soaked, transparent acrylic benthic flux chambers $(290 \times 290 \times$ $200 \mathrm{~mm}$ deep; approximate volume 16.8 l) were placed

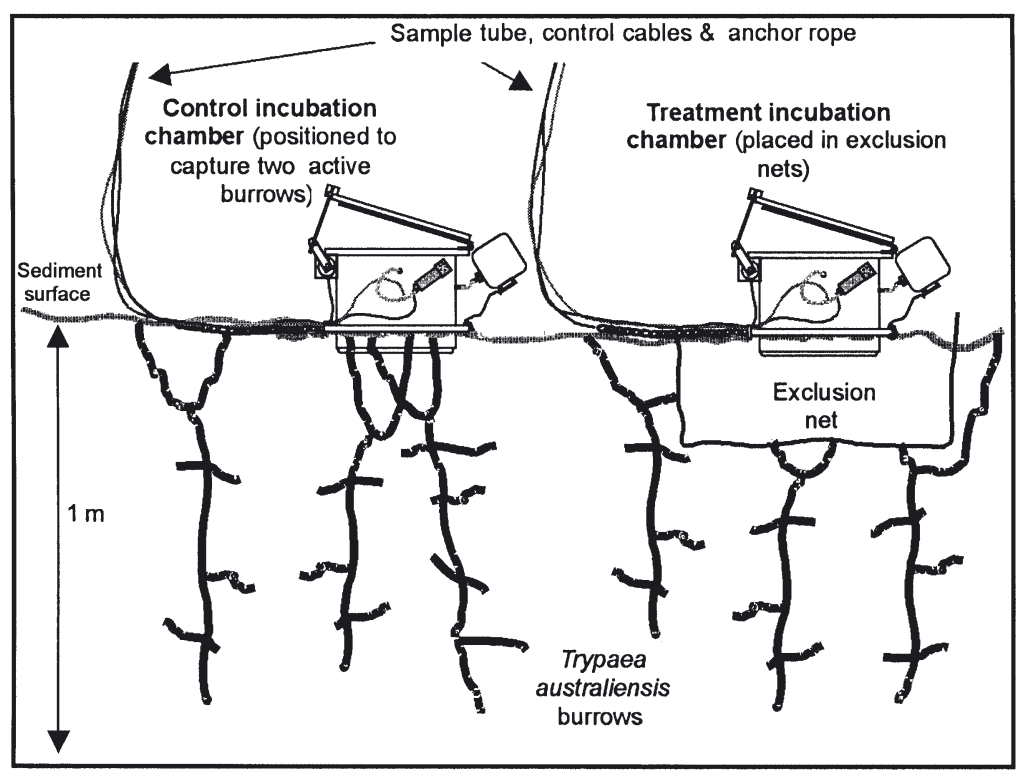

Fig. 2. Schematic showing control (left, Trypaea australiensis captured) and treatment (right, T. australiensis exclusion net) benthic-flux chamber incubations. Both chambers are shown with lids open during pre-incubation equilibration period; lids are closed and samples pulled via remote sample line into 4 of the 5 previously prepared exclusion nets (Fig. 2; treatments) and a single blank chamber with a sealed acrylic sheet base was placed in the 5th exclusion plot. All chambers were left for $12 \mathrm{~h}$ with their lids open prior to starting the incubation, allowing free movement of water into and out of the chamber, and settlement of any edge disturbance (this was observed to be negligible during chamber insertion). Rather than conventional rotational stirrers, the benthic flux chambers used for this study incorporated a 2D flow stirring system. This system was driven by individual submersible pumps which circulated the water within the chambers through diffusers, positioned to produce a consistent, unidirectional flow over the sediment surface. This system has been shown to not only adequately mix the headwater space, but also to produce less variation in the substratum diffusive boundary layer thickness, and emulates 'Bernoullian' flow through burrows more effectively than conventional rotational stirrers (Webb \& Eyre in press). The chamber pumps were pre-calibrated to give a linear water velocity within each chamber of approximately 1.20 to $1.50 \mathrm{~m} \mathrm{~min}^{-1}$ (mimicking the mean ambient flow conditions) and were also set to pulse $5 \mathrm{~min}$ on and 5 min off, again imitating the inconsistent flow regimes experienced within the bay. The chamber lids were sealed remotely at sundown on Day 1, and following lid closure $20 \mathrm{ml}$ of $3 \%$ caesium chloride $(\mathrm{CsCl})$ was injected into each chamber to give an estimated initial start concentration of approximately $35 \mathrm{ppm}$. CsCl was used as a water movement tracer after Berelson et al. (1999), and sediment irrigation was calculated by assuming that dilution was caused by the diffusion and active bio-irrigation of $\mathrm{CsCl}$-contaminated water into the sediments, to be replaced by uncontaminated water from the interstitial reservoir.

Samples were drawn from each chamber by a remote sample tube (Fig. 2) 8 times over each $24 \mathrm{~h}$ incubation, with the first $80 \mathrm{ml}$ being discarded $(80 \mathrm{ml}=$ volume of sample tubes plus $50 \%$ extra for tube flushing). A $150 \mathrm{ml}$ sample vessel with probe ports was filled from each chamber and dissolved oxygen (YSI 5000 dissolved oxygen probe, $\pm 0.01 \mathrm{mg} \mathrm{l}^{-1}$ ), $\mathrm{pH}$ and temperature (Denver AP25 pH probe, \pm 0.001 ) were recorded. A $12 \mathrm{ml}$ vial was filled with filtered $(0.45 \mu \mathrm{m})$ sample water and immediately frozen for dissolved nutrient analysis. A further $2 \times$ $12 \mathrm{ml}$ vials were filled with filtered $(0.45 \mu \mathrm{m})$ sample water and refrigerated at $4{ }^{\circ} \mathrm{C}$ for alkalinity titrations and $\mathrm{CsCl}$ 
analysis. Three $7 \mathrm{ml}$ gas-tight glass vials were also filled for $\mathrm{N}_{2} / \mathrm{Ar}$ analysis, and $20 \mu \mathrm{l}$ of $5 \% \mathrm{HgCl}_{2}$ was added immediately to each vial to stop bacterial activity (Eyre et al. 2002). Care was taken to exclude air bubbles when filling and capping glass vials, which were stored submerged in estuary water and kept stable at $19 \pm 1^{\circ} \mathrm{C}$ (mean ambient water temperature) until analysis $1 \mathrm{wk}$ later. Total sample volume extracted per period was ca. $290 \mathrm{ml}$ or approximately $1.7 \%$ of the chamber volume.

On completion of Incubation 1 (treatment incubation), the chambers were moved to Site 2 and placed over active Trypaea australiensis burrows for the control incubation. Site 2 was approximately $27 \mathrm{~m}$ from Site 1. This distance was considered an adequate buffer zone to avoid $\mathrm{CsCl}$ cross contamination and to avoid any sediment disturbance caused by activity at the first incubation site. Site 2 was similar to the treatment site in terms of water quality, depth, T. australiensis burrow density, sediment characteristics, proximity to seagrass beds, flow and current regimes. Prior to the second incubation, chambers were kept submerged, cleaned with a soft bush and flushed thoroughly with ambient water for $12 \mathrm{~h}$. They were inserted into the sediments inhabited by $T$. australiensis and the same deployment equilibration period of $12 \mathrm{~h}$ was maintained. The diffuser pump flow rate was not changed, and the control incubation commenced at sundown on Day 3. Trypaea australiensis burrow density was approximately 22 burrows $\mathrm{m}^{-2}$ at both incubation sites, and Kerr (2001) noted that where sparser $\left(<50\right.$ burrows $\left.\mathrm{m}^{-2}\right)$ T. australiensis burrow densities are found, the common inlet and outlet holes of a single burrow were often aligned or grouped, allowing easier identification of a single burrow network. A similar pattern of burrow vent alignment and grouping was observed at the study site, and a single burrow's vents could be found and contained within a 10 to $20 \mathrm{~cm}$ radius. Such vent groups were selected carefully and each control chamber was placed to capture 2 burrows.

Sediment oxygen micro-profiles. On completion of each incubation, 2 cores (90 $\mathrm{mm}$ inner diameter [ID] $\times$ $200 \mathrm{~mm}$ ) were removed from the sediments below each chamber maintaining the ambient water above the sediment. Burrows are known to have sediment irrigation/oxygenation effects which radiate out from the burrow wall (Aller 1988), and it was this phenomenon we hoped to capture. As such, the control sediment cores did not include the Trypaea australiensis burrows and were taken from sediments between these structures. One core was collected after sundown for a dark profile, and the second core was collected at midday of the following day for the light profile. The cores were taken immediately to base camp where oxygen microprofiles at $0.1 \mathrm{~mm}$ resolution were taken using an oxygen microsensor (Unisense OX 20) and micro-manipulator. The microsensor was calibrated using a YSI 5000 BOD probe simultaneously immersed in the column water. The head-water of each core was stirred continuously to maintain the diffusive boundary layer, and the cores were retained in ambient light conditions during analysis. In the interests of clearly presenting the main trends measured and to allow the ready comparison of the treatment and control profiles, error bars were not included on the mean microprofiles (see Fig. 4). Variability is alternatively expressed as the mean coefficient of variation of each profile type over all depths.

Sediment properties. Triplicate $50 \mathrm{~g}$ sediment samples were taken from the surface $20 \mathrm{~mm}$ of sediment below each chamber from both incubation sites using a $40 \mathrm{~mm}$ core. These were frozen for sediment grain-size analysis, bulk density and organic matter content. Triplicate sediment chl a samples were taken using a $40 \mathrm{~mm}$ core to extract a sediment profile. A $1 \mathrm{~cm}^{3}$ sample from the top $2 \mathrm{~mm}$ of sediment $\left(5 \mathrm{~cm}^{2}\right)$ was collected from the undisturbed profile and placed into prefilled (90\% acetone) $15 \mathrm{ml}$ centrifuge tubes. These samples were sealed, wrapped in foil and kept at $-20^{\circ} \mathrm{C}$ until analysis.

Light. Two PAR light loggers (Dataflow ${ }^{\mathrm{TM}}$ ) were deployed for the duration of each incubation and programmed to take 1 PAR irradiance reading per min. One was submerged, with the sensor remaining ca. $150 \mathrm{~mm}$ above the sediment surface, and the second was mounted $1 \mathrm{~m}$ above the high-water mark. Readings from both loggers were calibrated using a Licor 2 pi PAR irradiance sensor.

Laboratory analysis. Parameters analysed, abbreviations, analytical method and associated errors are summarised in Table 1 (Eyre 2000). All nutrient fractions were analysed using a Lachat flow injection analyser using standard colourimetric methods (Lachat 1994). Certified laboratory standards, Milli-Q water and low nutrient seawater were used to maintain analytical accuracy.

Solute flux calculations. Solute flux was calculated for both incubations using methods outlined in Eyre \& Ferguson (2002). Linear regression of solute concentration as a function of time, chamber volume (16.82 l) and sediment surface area $\left(0.084 \mathrm{~m}^{2}\right)$ were used to determine flux across the sediment-water interface. These rates were corrected for the addition of replacement water and changes in the blank chamber. Dark fluxes were calculated from the solute concentration change over the first $13 \mathrm{~h}$ of darkness, and light flux rates were correspondingly calculated from the following $11 \mathrm{~h}$ light period. Gross benthic production (light rates) were calculated as: light $\mathrm{O}_{2}$ flux (positive) - dark $\mathrm{O}_{2}$ flux (negative). 
Table 1. Nutrient forms, abbreviations, analytical procedures, detection limits and analytical errors (after Eyre 2000)

\begin{tabular}{|c|c|c|c|c|}
\hline Parameter & Abbreviation & Method & Error $(\%)$ & Source \\
\hline Dissolved inorganic phosphorous & DIP & Ascorbic acid & 2.3 & Lachat (1994) \\
\hline Nitrite & $\mathrm{NO}_{2}$ & Sulphanilamide & 2.8 & Lachat (1994) \\
\hline Nitrate & $\mathrm{NO}_{3}$ & Cadmium reduction & 3.6 & Lachat (1994) \\
\hline Ammonium & $\mathrm{NH}_{4}$ & Hypochlorite/phenolate & 5.1 & Lachat (1994) \\
\hline Di-nitrogen gas & $\mathrm{N}_{2}$ & $\begin{array}{l}\text { Membrane inlet mass } \\
\text { spectrometer with } \mathrm{O}_{2} \text { removal }\end{array}$ & 0.01 & Eyre et al. (2002) \\
\hline Alkalinity & & Gran titration & 1.0 & Stumm \& Morgan (1996) \\
\hline Total carbon dioxide & $\mathrm{TCO}_{2}$ & Standard equations & & Almgren et al. (1983) \\
\hline Caesium & $\mathrm{Cs}$ & $\begin{array}{l}\text { Inductively coupled plasma } \\
\text { mass spectrometer }\end{array}$ & $<1$ & Eaton et al. (1995) \\
\hline Chl a biomass & & $\begin{array}{l}\text { Acetone extraction- } \\
\text { spectrophotometer }\end{array}$ & 4.1 & Eaton et al. (1995) \\
\hline
\end{tabular}

Both light and dark flux were expressed as hourly rates $\left(\mathrm{h}^{-1}\right)$. Net rates were calculated as the average of the dark and light effluxes and expressed as daily $(24 \mathrm{~h})$ rates $\left(\mathrm{d}^{-1}\right)$.

Student's $t$-tests assuming unequal variance were used to detect significant differences, and confidence values (p) are shown where significant differences were detected; otherwise 0.05 was the confidence level cut-off. Data was normally distributed and was tested for normality using SPSS 10, Shapiro-Wilks normality tests and post-hoc power analysis was also undertaken. The errors associated with the calculated rates include the standard deviation between the 4 chambers of each incubation and the error resulting from instrument and analytical precision.

\section{RESULTS}

\section{Tracer (caesium chloride) behaviour}

Caesium (Cs) concentrations decreased over $24 \mathrm{~h}$ in both the treatment and control incubations (Fig. 3a). One of the control chambers, however, showed a dramatic decline in Cs concentration, dropping to an undetectable concentration $(<0.1 \mathrm{ppm})$ within $5 \mathrm{~h}$ of starting the incubation. This chamber most likely contained a burrow, or burrows, which was open to the outside water column and was irrigated actively or flushed with fresh outside waters for the duration of the incubation; as such, data from this chamber were not used. In contrast, the similar linear Cs concentration reductions seen over the $24 \mathrm{~h}$ incubations suggests that the remaining chambers were well sealed within the treatment and control sediments, and that the burrows contained within each control chamber were isolated from the outside water column. Furthermore, mean conductivity did not change significantly in either the remaining control chambers (start to to finish: 49.6 to $50.1 \mathrm{~ms} \mathrm{~cm}^{-1}$ ) or the treatment (start to finish: 54.4 to $53.8 \mathrm{~ms} \mathrm{~cm}^{-1}$ ).

The mean Cs concentration in the treatment chambers decreased by $38 \%$ in $24 \mathrm{~h}$, from $35.2 \pm 3.6$
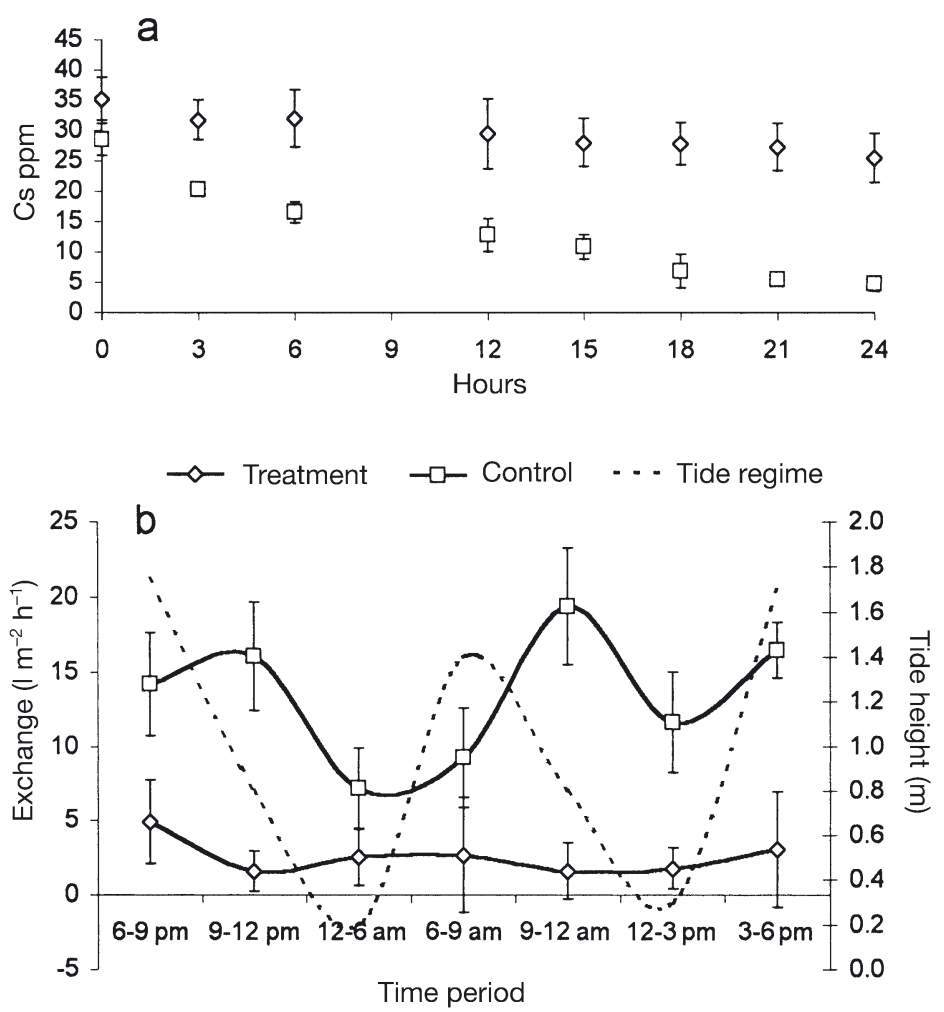

Fig. 3. (a) Comparative mean caesium chloride concentration extinction over time, and (b) comparative $24 \mathrm{~h}$ sediment exchange/irrigation rate calculated from Cs extinction, showing the relationship between the control rate change and tidal movement 
to $25.4 \pm 3.7 \mathrm{ppm}$. In contrast, the control sediments inhabited by Trypaea australiensis showed an $88 \%$ drop in mean Cs concentration over the course of the incubation, from $29.5 \pm 3.1$ to $3.7 \pm 2.3 \mathrm{ppm}$. Sediment porewater exchange rates within the chambers of each incubation were calculated from the measured decrease in Cs concentrations (dilution due to exchange) over time. The mean control $24 \mathrm{~h}$ sediment irrigation/exchange rate $\left(429.4 \mathrm{l} \mathrm{m}^{-2} \mathrm{~d}^{-1}\right)$ was over 5-fold greater than the treatment sediments $\left(77.2 \mathrm{l} \mathrm{m}^{-2}\right.$ $\mathrm{d}^{-1}$ ), and showed more variation than the treatment incubation (Fig. 3b). Cs is adsorbed onto sediment particles (Townsend 1998), and the determination of sediment exchange and irrigation rates using Cs dilution over time may be underestimated due to adsorption onto resuspended particles and the sediment surface. The determination of standard correction coefficients is problematic as adsorption rates vary with differing sediment types (Townsend 1998, Berelson et al. 1999). Since the sediment type was the same in both incubations, the adsorption rate is assumed to be similar in both incubations. However, the increased surface area associated with $T$. australiensis burrows in the control chambers may have increased the relative adsorption capacity of the control incubations to a level over that of the treatments.

\section{Sediment properties}

The mean ratio of burrow inlets to outlets was 1:1.3, indicating that each burrow usually had a single inlet and single outlet. Kerr (2001) found a similar pattern during his study in the neighbouring Richmond River estuary. The mean density of Trypaea australiensis burrows within Readings Bay was calculated as the mean number of inlets and outlets divided by 2 . This gave $50.6 \pm 15.9$ individual burrows $\mathrm{m}^{-2}$, with a mean inlet burrow diameter of $10.7 \pm 1.6 \mathrm{~mm}$ and outlet diameter of $7.5 \pm 1.6 \mathrm{~mm}$. Burrow densities were lower in subtidal areas $\left(<30\right.$ burrows $\left.\mathrm{m}^{-2}\right)$ and higher $(>50$ burrows $\mathrm{m}^{-2}$ ) in the intertidal zone, and there were approximately 22 burrows $\mathrm{m}^{-2}$ at the incubation sites.

The study site sediments consisted of well sorted, coarse to medium quartz sands (96\% of grains being 0.5 to $0.13 \mathrm{~mm}$ ). The upper $20 \mathrm{~mm}$ of sediment from each location showed a slight variation in grain size proportions and organic matter content. The control plot sediments had a greater proportion of finer particles ( $69 \%$ of 0.25 to $0.13 \mathrm{~mm}$ and $26 \%$ of 0.5 to $0.25 \mathrm{~mm}$ ) compared to sediments from the treatment plots, which had approximately equal proportions in each (49 and $48 \%$ respectively). Bulk density in the upper $10 \mathrm{~mm}$ of sediment was slightly, but significantly, different between sites $(p<0.011)$, with the treatments and control plots having a porosity of $19.7 \pm 0.2$ and $20.8 \pm 0.8 \%$ respectively. Sediment mean organic matter content was also slightly, but not significantly, higher $(13 \%)$ in the control sediments $(12.16 \pm 1.29 \mathrm{mg}$ $\mathrm{g}^{-1}$ ) compared to the treatment sediments (10.6 \pm $1.3 \mathrm{mg} \mathrm{g}^{-1}$ ). Mean sediment surface chl a concentrations were significantly different $(p<0.001)$, with the treatment concentration $\left(30.5 \pm 5.7 \mathrm{mg} \mathrm{m}^{-2}\right)$ being 2-fold that of the control sediments $\left(17.0 \pm 3.2 \mathrm{mg} \mathrm{m}^{-2}\right)$.

Dissolved oxygen (DO) micro-profiles (Fig. 4) taken from the treatment sediments at midday (peak production period) showed a consistent pattern of saturation at the sediment surface, with the mean $\mathrm{O}_{2}$ concentration increasing linearly $\left(\mathrm{r}^{2}=0.95\right)$ from approximately $280 \mu \mathrm{mol} \mathrm{l}^{-1}$ (upper diffusive boundary layer) to $488 \mu \mathrm{mol} \mathrm{l} \mathrm{l}^{-1}$ (0.4 mm below sediment surface). The treatment mean $\mathrm{O}_{2}$ concentration then decreased from $0.4 \mathrm{~mm}$ to undetectable concentrations at $4.3 \mathrm{~mm}$ depth. In contrast, the control sediment surface was less $\mathrm{O}_{2}$-saturated, and showed a far smaller mean $\mathrm{O}_{2}$ increase (from ca. $280 \mu \mathrm{mol} \mathrm{l}^{-1} 1 \mathrm{~mm}$ above the sediment to $258 \mu \mathrm{mol} \mathrm{l}^{-1}$ at the sediment surface). The decrease in the mean control sediment $\mathrm{O}_{2}$ concentra-
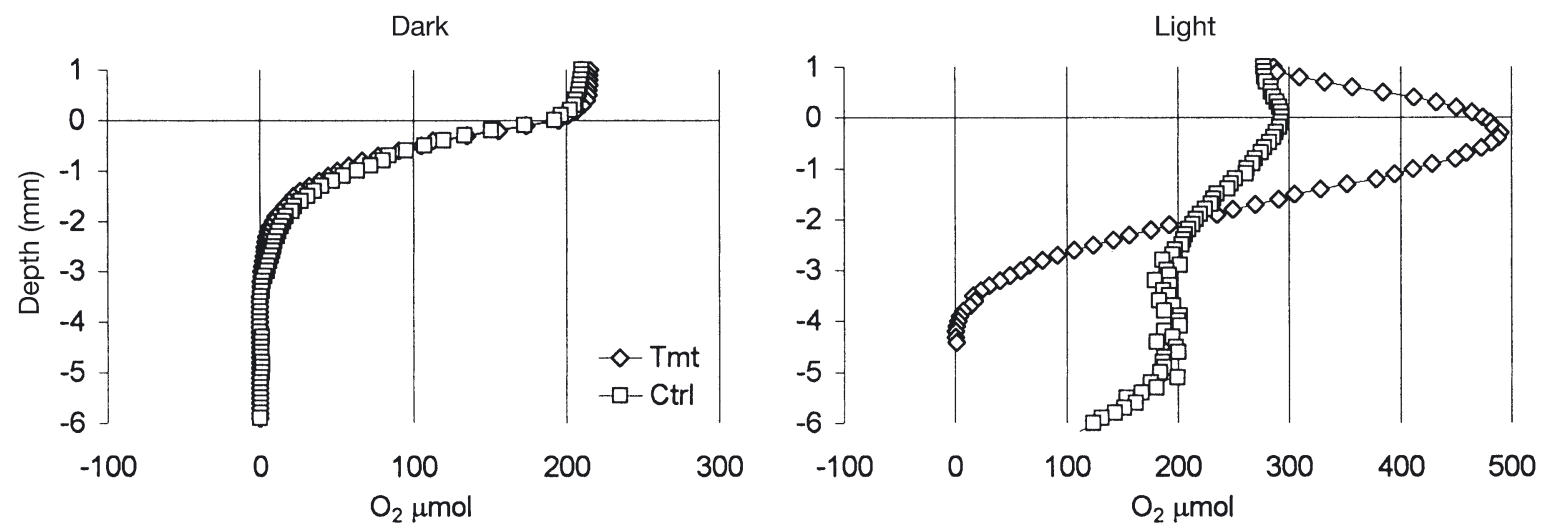

Fig. 4. Comparative mean dark and light $\mathrm{O}_{2}$ microprofiles 
tion with depth was far more variable than the treatment sediments, with a $40 \%$ mean coefficient of variation over all depths compared to $17 \%$ for treatment sediments. Penetration depth $(>8.5 \mathrm{~mm})$ was almost double that of the treatment sediments.

The mean dark control and treatment profiles were very similar (Fig. 4). However, greater variation was again evident in the control sediments (CV 66\%) compared to the treatment $(\mathrm{CV} 15 \%)$ and mean $\mathrm{O}_{2}$ penetration was slightly deeper (about $0.5 \mathrm{~mm}$ ) in the controls.

\section{Benthic productivity and respiration}

Light intensity measurements (PAR) from both incubations were not significantly different and had mean daily values of $745 \pm 32$ and $395 \pm 46 \mu \mathrm{mol} \mathrm{s} \mathrm{s}^{-1}$ for air and submerged (0.4 to $2.2 \mathrm{~m}$ deep) 2 pi sensors, respectively. Photosynthetic potential was not considered different during either incubation.

There was no significant difference between any of the treatment and control $\mathrm{O}_{2}$ or total $\mathrm{CO}_{2}\left(\mathrm{TCO}_{2}\right)$ fluxes (power $=0.76$ and 1.00, respectively; Fig. 5). However, mean control sediment $\mathrm{O}_{2}$ consumption (1691 \pm $580 \mu \mathrm{mol} \mathrm{O}_{2} \mathrm{~m}^{-2} \mathrm{~h}^{-1}$ ) was ca. $55 \%$ greater than the mean treatment $\mathrm{O}_{2}$ consumption (932 $\pm 96 \mu \mathrm{mol} \mathrm{O} \mathrm{O}_{2} \mathrm{~m}^{-2}$ $\mathrm{h}^{-1}$ ), and sediment $\mathrm{O}_{2}$ production rates were ca. $15 \%$ greater in the control sediments $\left(6586 \pm 1011 \mu \mathrm{mol} \mathrm{m}{ }^{-2}\right.$ $\left.\mathrm{h}^{-1}\right)$ than the treatment sediments $\left(5622 \pm 284 \mu_{\mathrm{mol} \mathrm{m}}{ }^{-2}\right.$ $\mathrm{h}^{-1}$ ). Both the control and treatment sediments were net autotrophic, showing net $(24 \mathrm{~h}) \mathrm{O}_{2}$ effluxes of $31854 \pm 1900$ and $39468 \pm 1000 \mu \mathrm{mol} \mathrm{O} \mathrm{O}^{-2} \mathrm{~d}^{-1}$ respectively. Mean (24 h) $\mathrm{TCO}_{2}$ fluxes (Fig. 5) showed
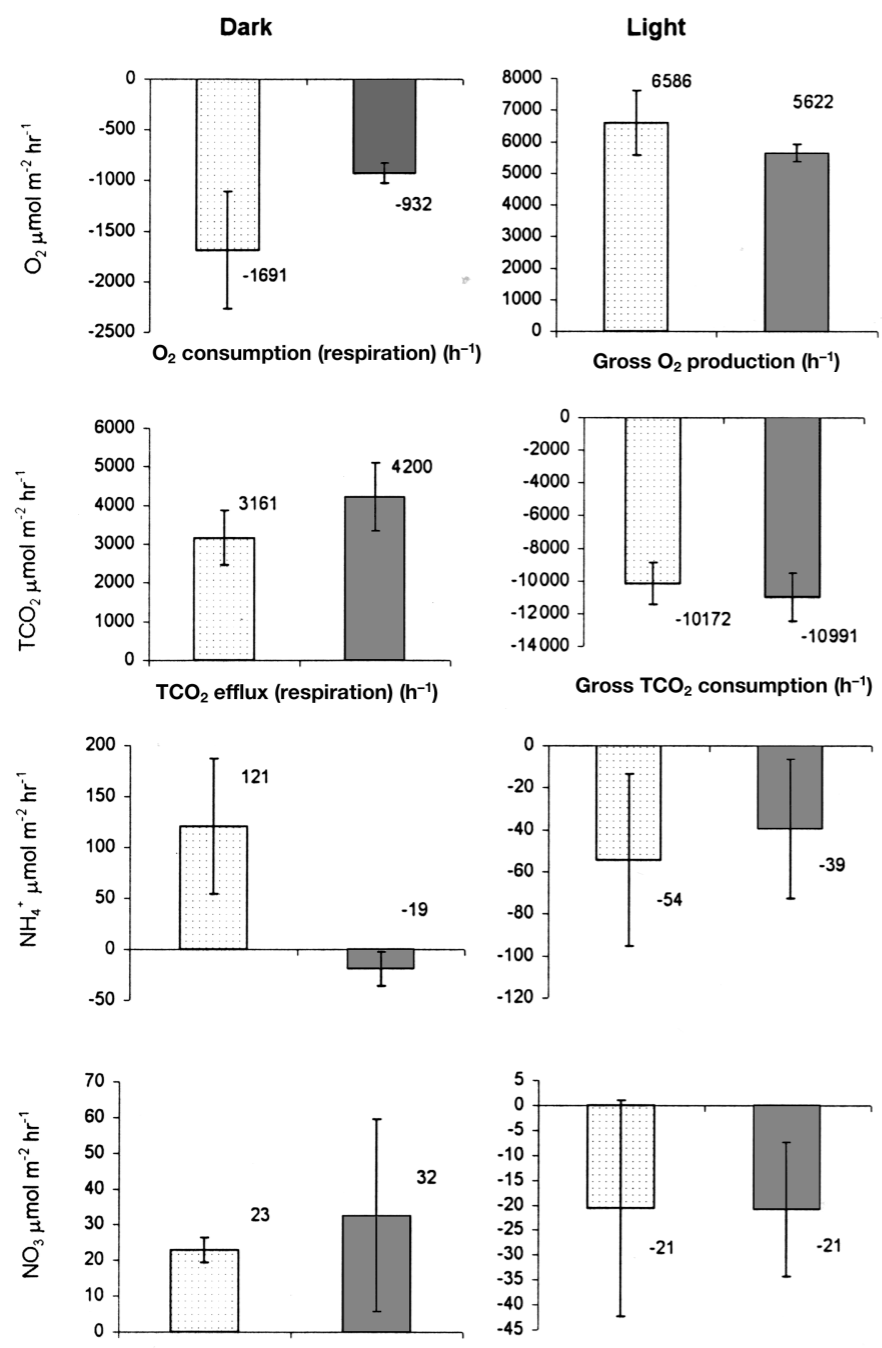
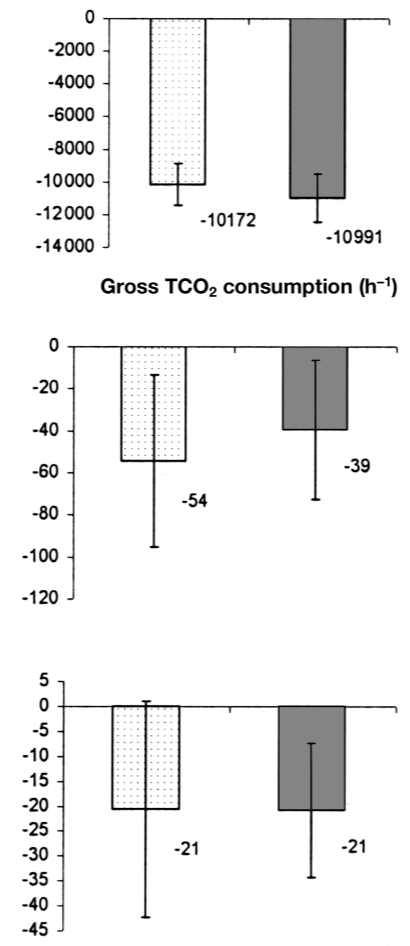
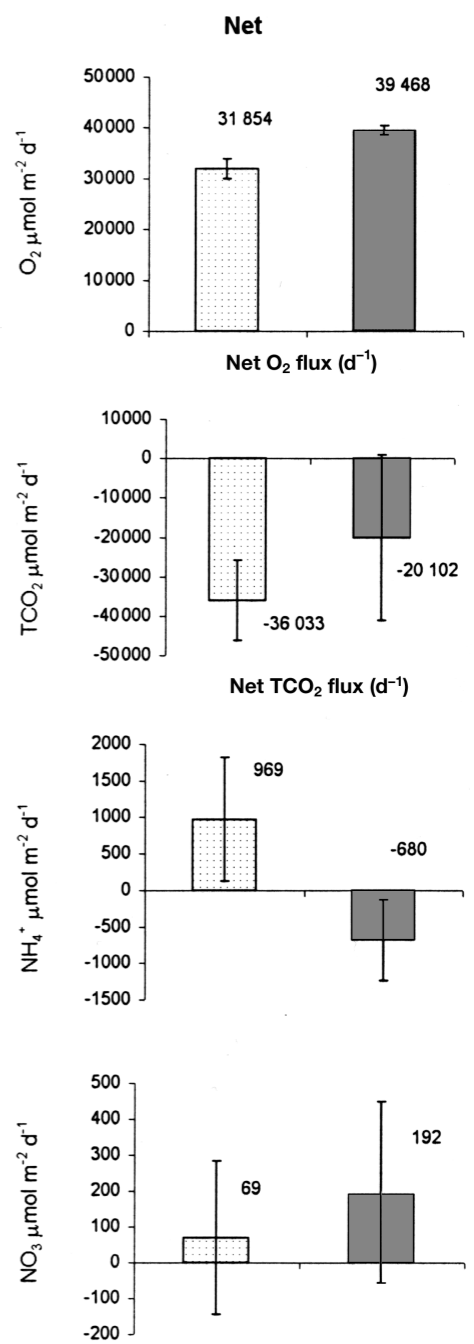

Fig. 5. Comparative control (light shading) and treatment (dark shading) $\mathrm{O}_{2}$, total $\mathrm{CO}_{2}\left(\mathrm{TCO}_{2)}, \mathrm{NH}_{4}{ }^{+}, \mathrm{NO}_{3}^{-}, \mathrm{NO}_{2}^{-}, \mathrm{N}_{2}\right.$ and $\mathrm{PO}_{4}$ dark, light (hourly) and net $(24 \mathrm{~h})$ mean flux rates (negative rates indicate net movement of solute into sediments) 
a net efflux in both the control $(36033 \pm 10128 \mu \mathrm{mol}$ $\left.\mathrm{m}^{-2} \mathrm{~d}^{-1}\right)$ and treatment $\left(20102 \pm 20922 \mu \mathrm{mol} \mathrm{m} \mathrm{m}^{-2} \mathrm{~d}^{-1}\right)$. The mean dark and light fluxes also showed similar patterns of net efflux $(3161 \pm 706$ and $4199 \pm$ $\left.886 \mu \mathrm{mol} \mathrm{m} \mathrm{m}^{-2} \mathrm{~h}^{-1}\right)$ and uptake (10172 \pm 1286 and $10991 \pm 1487 \mu \mathrm{mol} \mathrm{m} \mathrm{m}^{-2} \mathrm{~h}^{-1}$ ) in the control and treatment sediments respectively.

\section{Nutrient efflux}

Dark and net ammonium $\left(\mathrm{NH}_{4}{ }^{+}\right)$fluxes showed a significant difference $(\mathrm{p}<0.030)$ between the control and treatment (Fig. 5). The control net (24 h) $\mathrm{NH}_{4}{ }^{+}$ efflux was $969 \pm 846 \mu \mathrm{mol} \mathrm{m}{ }^{-2} \mathrm{~d}^{-1}$ compared to a net uptake of $680 \pm 555 \mu \mathrm{mol} \mathrm{m} \mathrm{m}^{-2} \mathrm{~d}^{-1}$ in the treatment sediments. The control net $\mathrm{NH}_{4}{ }^{+}$efflux reflected the $\mathrm{NH}_{4}{ }^{+}$dark efflux $\left(121 \pm 66 \mu \mathrm{mol} \mathrm{m}{ }^{-2} \mathrm{~h}^{-1}\right)$, which contrasted with a small $\mathrm{NH}_{4}{ }^{+}$uptake $\left(19 \pm 17 \mu \mathrm{mol} \mathrm{m}{ }^{-2}\right.$ $\mathrm{h}^{-1}$ ) in the treatment sediments. Similar $\mathrm{NH}_{4}{ }^{+}$light uptake rates were evident in the control and treatment sediments $\left(54 \pm 41\right.$ and $\left.39 \pm 33 \mu \mathrm{mol} \mathrm{m}{ }^{-2} \mathrm{~h}^{-1}\right)$ respectively.

Net $24 \mathrm{~h}$ nitrate $\left(\mathrm{NO}_{3}{ }^{-}\right)$and nitrite $\left(\mathrm{NO}_{2}{ }^{-}\right)$fluxes in the control and treatment sediments were not statistically different (power $=0.136$ and 0.315 respectively) .
Mean $24 \mathrm{~h} \mathrm{NO}_{3}^{-}$efflux in the treatments (192 \pm $256 \mu \mathrm{mol} \mathrm{m} \mathrm{m}^{-2} \mathrm{~h}^{-1}$ ) was approximately $280 \%$ greater than the control $\left(69 \pm 213 \mu \mathrm{mol} \mathrm{m} \mathrm{m}^{-2} \mathrm{~h}^{-1}\right)$, and $\mathrm{NO}_{2}{ }^{-}$ showed a net efflux in the treatment sediments compared to a net uptake in the control sediments (Fig. 5). The net $24 \mathrm{~h}$ fluxes were due to larger dark $\mathrm{NO}_{3}{ }^{-}(42 \%$ greater) and $\mathrm{NO}_{2}^{-}$(421\% greater) mean efflux rates in the treatment sediments.

Mean net and dark $\mathrm{N}_{2}$ effluxes were significantly different $(p<0.001)$ between the control and treatment sediments. The control dark $\mathrm{N}_{2}$ efflux (316 $\pm 112 \mu \mathrm{mol}$ $\mathrm{m}^{-2} \mathrm{~h}^{-1}$ ) was over 7 times greater than the dark treatment efflux $\left(44 \pm 41 \mu \mathrm{mol} \mathrm{m} \mathrm{m}^{-2} \mathrm{~h}^{-1}\right)$ and correspondingly, the net 24 efflux of $\mathrm{N}_{2}$ in the control sediments was over 4 times greater than in the treatment sediments. Mean control light $\mathrm{N}_{2}$ effluxes decreased; however, they were still approximately $35 \%$ greater than in the treatment sediments (Fig. 5).

There was no significant difference (power $=0.256$ ) between mean phosphate $\left(\mathrm{PO}_{4}{ }^{3-}\right)$ fluxes. However, the mean control dark $\mathrm{PO}_{4}{ }^{3-}$ efflux $\left(8.7 \pm 8.9 \mu \mathrm{mol} \mathrm{m}{ }^{-2} \mathrm{~h}^{-1}\right)$ was greater than the treatment mean $(0.1 \pm 1.3 \mu \mathrm{mol}$ $\mathrm{m}^{-2} \mathrm{~h}^{-1}$ ), and net $24 \mathrm{~h} \mathrm{PO}_{4}{ }^{3-}$ fluxes showed a net efflux in the control sediments $\left(156 \pm 260 \mu \mathrm{mol} \mathrm{m} \mathrm{m}^{-2} \mathrm{~d}^{-1}\right)$ and net consumption $\left(31 \pm 51 \mu \mathrm{mol} \mathrm{m} \mathrm{m}^{-2} \mathrm{~d}^{-1}\right)$ in the treatment sediments.

\section{Dark}
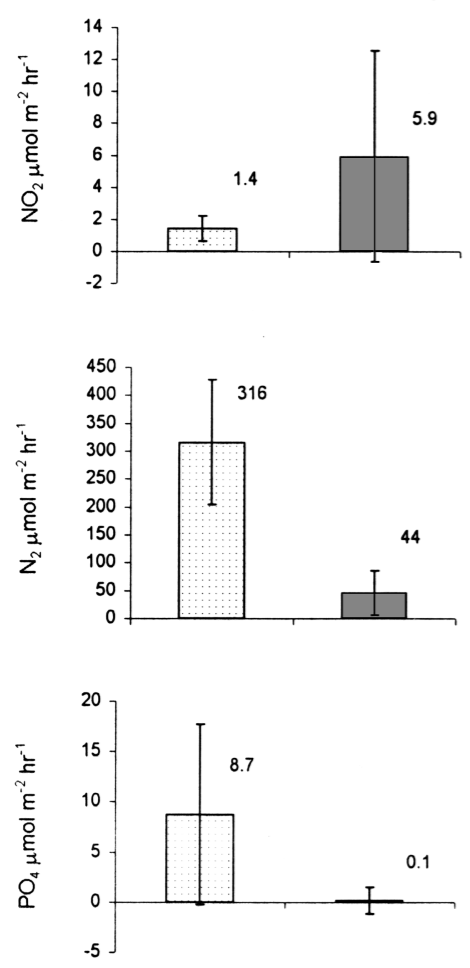

Light
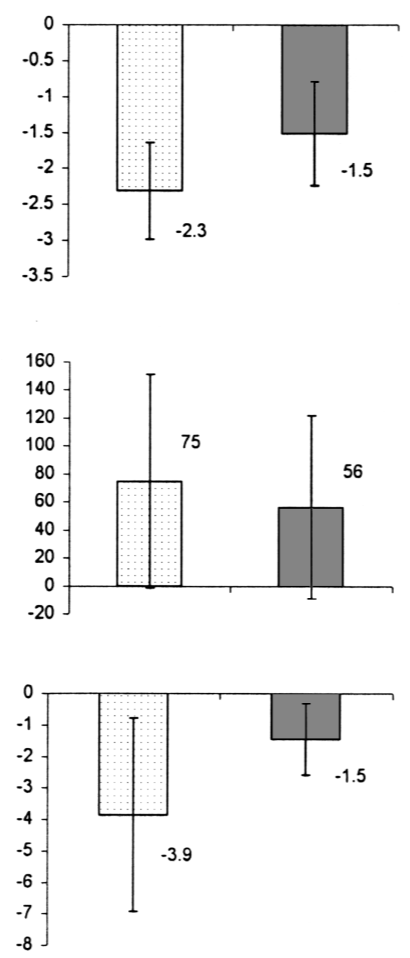

Fig. 5 (continued)
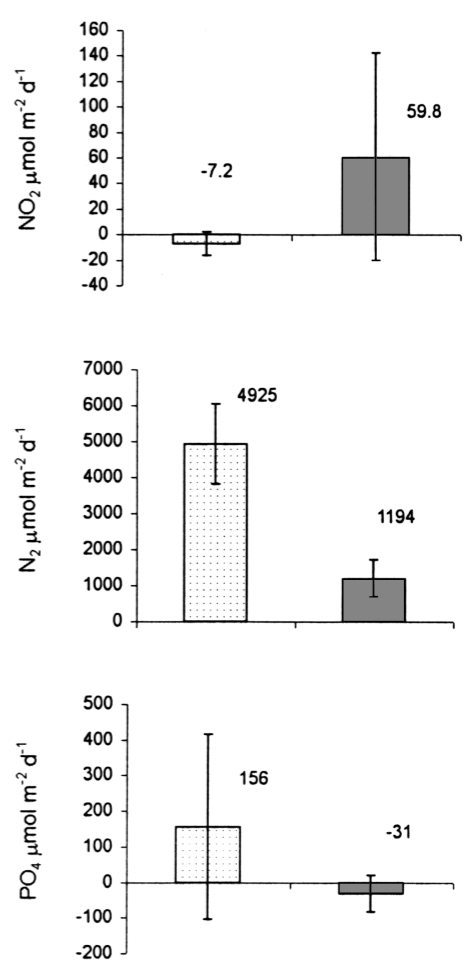


\section{DISCUSSION}

\section{Experimental design}

The experimental design used in this study may not be considered ideal, due to the lack of site (experimental unit) replication to account for variability within the study area, and due to the lack of a treatment control (see Underwood 1997). Site replication using in situ chambers is logistically difficult, and would have required a lengthy (several weeks) extension of the incubation period which, in turn, would have led to the introduction of confounding effects of temporal variability due to inevitable changes in environmental factors (e.g. light, tide, salinity, flow, transport, weather, etc.). As such, we concentrated our effort into replication at 1 site. We consider our experimental design appropriate because an earlier pilot study (A. P. Webb unpubl. data) using simultaneous triplicate $(24 \mathrm{~h})$ incubations of sediments from 3 locations within the bay showed that both respiration and productivity had a spatial variability of less than $12 \%(\% \mathrm{CV})$. This degree of variability is an order of magnitude less than the differences we expected (and found) between control and treatment incubations.

This minimum disturbance, in situ work combined with the habits and size of the target species, also restricted our ability to test for treatment artefacts (i.e. dig up and replace sediments without using an exclusion net to test for possible effects of the treatment preparation, by allowing recruitment of these sediments and their comparison to the control sediments). This was not undertaken as Trypaea australiensis is a long-lived species (up to $2 \mathrm{yr}_{\text {; }}$ Hailstone \& Stephenson 1961) and studies of similar species suggest it may take over 12 mo to construct a mature burrow system (Forster \& Graf 1995) due to the complex and extensive nature of their burrowing habits. It was not possible to leave our exclusion plots for this amount of time, as we witnessed recruitment into similar exclusion nets during earlier trials (presumably via the water column) after approximately $2 \mathrm{mo}$. Instead, we incorporated the maximum possible treatment equilibration period (40 d) as a compromise between the risk of re-colonisation of the exclusion sediments by $T$. australiensis and the adequate recovery of sediment biota, particularly denitrifying bacteria.

The $40 \mathrm{~d}$ equilibration period was considered adequate for a number of reasons. In situ recovery experiments by Davis \& Lee (1983) showed that benthic chl a and gross productivity of sieved $(1 \mathrm{~mm})$ and frozen sediments returned to previous levels after $10 \mathrm{~d}$ following their reintroduction into the field. Similarly, an earlier pilot study (data not shown), using exclusion nets within the study embayment, showed that chl a biomass and oxygen production and consumption was not significantly different $(\mathrm{p}<0.05)$ between undisturbed and exclusion net sediments after $18 \mathrm{~d}$ equilibration. Meiofauna assemblages and biomass may also be affected by disturbance; however, meiofauna abundance and community at this location were insignificantly different to undisturbed sediments after 1 to $2 \mathrm{wk}$ following disturbance by wallowing rays (Ahern 2001).

Microbial biomass and activity are interrupted by sediment disturbance; however, effective recovery of the microbial community has been observed to occur within hours (Findlay et al. 1990). Conversely, sieving sediments through a $1 \mathrm{~mm}$ mesh reduced denitrifying enzyme assays by up to $70 \%$ and denitrifying bacterial biomass by up to $90 \%$ in the upper $20 \mathrm{~mm}$ of sediment, and denitrification potential returned to near initial values only after $82 \mathrm{~d}$ incubation time during laboratory experiments by Gilbert et al. (1995). The experiment by Gilbert et al. (1995) highlights the importance of an adequate equilibration period following complete disturbance of sediment horizons. The preparation of sediments in the exclusion nets for this study did not involve sieving or deliberate homogenising, and the sediment was replaced to its respective location almost immediately (in distinct approximately $50 \mathrm{~mm}$ thick layers). The exclusion net mesh was sufficiently large $\left(1.5 \mathrm{~mm}^{2}\right)$ to allow free movement of meiofauna and microorganisms and not inhibit solute transport, it was completely open at the surface, and normal regimes of recruitment, settlement, illumination and tidal flushing could occur for the duration of the equilibration period. Since the treatment sediments retained all infauna other than Trypaea australiensis, it is likely that denitrifying population recovery was also greatly accelerated, as Gilbert et al. (1995) also found that infauna significantly enhanced denitrifying bacterial populations and denitrifying enzyme assay recovery over that of uninhabited sediment. In light of the sediment preparation techniques used, inclusion of infauna and the intensive regimes of natural disturbance occurring within the study embayment, the $40 \mathrm{~d}$ equilibration period was considered sufficient for the recovery of microalgal, meiofaunal and bacterial assemblages and function (albeit modified due to the exclusion of $T$. australiensis).

Despite compromises in the statistical design of this study, the in situ approach used here is presented as an effective method of measuring the biogeochemical influence of such large infaunal species, where their complex burrowing habits, longer life cycles and shy nature prevent the use of more easily replicated ex situ methods. 


\section{Sediment properties}

Mean chl a concentration in the upper $2 \mathrm{~mm}$ of the treatment sediments was nearly 2 -fold higher than that of the control sediments (30.5 and $17.0 \mathrm{mg} \mathrm{m}^{-2}$, respectively). Sediment surface chl a concentrations may decline in the presence of infauna where high rates of disturbance and burial occur (Davis \& Lee 1983, Page et al. 1992). The active burrow outlets of Trypaea australiensis caused the formation of fresh 'volcano'shaped mounds of dark (reduced) sediments (5 to $10 \mathrm{~cm}$ in diameter and 2 to $4 \mathrm{~cm}$ high), and funnelshaped pits were evident at the inlets. The constant replenishment of the outlet mounds (10 to $15 \mathrm{~g}$ dry weight per tidal cycle; Kerr 2001) would prevent microphytobenthos settling on these mounds and cause cell burial. Resuspended microalgal cells and other detritus also collect in macrofauna inlet funnels and enter the burrow during irrigation (Nickell \& Atkinson 1995, Botto \& Iribarne 2000), and diatoms (a common component of microphytobenthic communities) are a regular component of the gut contents of $T$. australiensis (Kenway 1981). Sediment surface disturbance, and possibly ingestion associated with the activities of $T$. australiensis, probably led to the reduced chl a concentrations measured on the surface of the control sediments. This same process of recycling of water through the respiratory loop of T. australiensis burrows, and deposition of fine particles onto the exhalent mound, is also the likely mechanism which caused the greater abundance of finer particles to settle in the upper $20 \mathrm{~mm}$ of the control sediment (particles in the 0.25 to $0.13 \mathrm{~mm}$ range being approximately $20 \%$ more abundant).

Microalgal biomass correlates with autotrophic productivity (e.g. Nixon 1995, Valiela 1995, Harris et al. 1996, Ferguson 2001) and associated with the 2-fold greater chl a concentrations found in the treatment sediments, increased oxygen production was also expected. However, gross $\mathrm{O}_{2}$ production was not significantly different between the control and treatment sediments (6586 and $5622 \mu \mathrm{mol} \mathrm{m} \mathrm{m}^{-2} \mathrm{~h}^{-1}$, respectively). Only the ambient upper sediment surface ( $2 \mathrm{~mm})$ was analysed for chl a concentration, and greater or similar microphytobenthic biomass may have remained undetected in deeper control sediment layers or within the Trypaea australiensis burrow structures. Branch \& Pringle (1987) also found that surface microphytobenthos biomass was greater within in situ nets excluding the burrowing shrimp Callianassa kraussi. However, total microphytobenthos biomass (in the combined surface and deeper sediments) was also greatest in sediments containing C. kraussi. High concentrations of

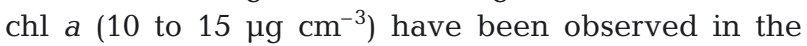
upper surfaces of T. australiensis burrows (Kerr 2001), indicating that like Branch \& Pringle's (1987) study, higher concentrations of microphytobenthic biomass may have been present in the control sediments but were undetected by the sampling technique employed.

\section{Sediment metabolism}

The control and treatment sediments were both net autotrophic with net $\mathrm{O}_{2}$ effluxes of $31854 \pm 1946$ and $39468 \pm 973 \mu \mathrm{mol} \mathrm{m}{ }^{-2} \mathrm{~d}^{-1}$, respectively. Net productivity in the control sediment was approximately $23 \%$ lower than the treatment sediment, and resulted from greater (approximately $81 \%$ ) sediment $\mathrm{O}_{2}$ consumption rates, rather than higher gross productivity in the treatment sediments. The presence and activities of macrofauna and their burrows significantly increase sediment $\mathrm{O}_{2}$ demand resulting from the enhancement of oxidation reactions such as sulphide and pyrite oxidation, nitrification, and/or the increased respiration from the macrofauna population and associated microbial communities (Koike \& Mukai 1983, Vetter \& Hopkinson 1985, Aller 1988, Kristensen et al. 1991, Pelegri et al. 1994, Paterson \& Thorne 1995, Pelegri \& Blackburn 1995). Macrofauna also stimulate the meiobenthic community size and structure (Dittmann 1996, Lillebo et al. 1999) and meiobenthic biomass correlates positively to the presence of Trypaea australiensis burrows (Kerr 2001). Increased meiobenthic biomass may have increased the control sediment's $\mathrm{O}_{2}$ demand in comparison to the treatment sediments, and could also reduce chl a concentrations in the control sediments due to increased grazing pressure.

The presence of burrowing macrofauna can stimulate both $\mathrm{CO}_{2}$ efflux and $\mathrm{O}_{2}$ consumption due to increased sediment surface area and enhanced sediment metabolism (Aller 1988, Banta et al. 1999, Kristensen 2000). A nearly 2-fold greater (dark) $\mathrm{O}_{2}$ consumption rate was measured in the control sediments

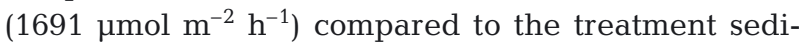
ments $\left(932 \mu \mathrm{mol} \mathrm{m} \mathrm{m}^{-2} \mathrm{~h}^{-1}\right)$. Aerobic respiration should result in $\mathrm{O}_{2}$ consumption and $\mathrm{CO}_{2}$ efflux ratios of approximately 1:1 (Aller 1982, Eyre \& Ferguson 2002); however, both the control (1:1.9) and treatment (1:4.5) showed unbalanced $\mathrm{O}_{2}$ consumption and $\mathrm{TCO}_{2}$ efflux ratios, with an almost 2 -fold greater $\mathrm{TCO}_{2}$ efflux in the treatment sediments over the control. Other burrowing infauna (polychaetes) may inhibit anaerobic decomposition (due to increased irrigation rates) and decrease sulphate reduction rates by up to $85 \%$ compared to defaunated sediment (Banta et al. 1999). The increased irrigation rates and resulting enhanced oxygen supply to deeper sediments, associated with the activities of Trypaea australiensis, likely augmented sulphide oxi- 
dation rates and inhibited sulphate reduction rates, resulting in the comparatively lower $\mathrm{TCO}_{2}$ efflux rates measured in the control sediments. In contrast, the greater $\mathrm{TCO}_{2}$ flux in the treatment sediments possibly reflects the comparative lack of oxygenation of deeper sediments due to the exclusion of $T$. australiensis burrowing and sediment irrigation activities.

The mean $\mathrm{O}_{2}$ consumption rate for the treatment sediments was $932 \pm 96 \mu \mathrm{mol} \mathrm{m} \mathrm{m}^{-2} \mathrm{~h}^{-1}$, compared to $1691 \pm 580 \mu \mathrm{mol} \mathrm{m} \mathrm{m}^{-2} \mathrm{~h}^{-1}$ in the control sediments inhabited by Trypaea australiensis. By subtracting the treatment rate from the control rate, the remainder ( $759 \mu \mathrm{mol} \mathrm{m}{ }^{-2} \mathrm{~h}^{-1}$ ) can be attributed to the presence of T. australiensis. If this mean rate is divided by burrow number (approximately 22 burrows $\mathrm{m}^{-2}$ ), an approximation of individual burrow + organism $\mathrm{O}_{2}$ consumption rates can be calculated (33 $\left.\mathrm{mmol}_{\text {burrow }}{ }^{-1} \mathrm{~h}^{-1}\right)$. Average individual $\mathrm{O}_{2}$ respiration rates for $T$. australiensis are $4.81 \mu \mathrm{mol} \mathrm{h}{ }^{-1}$ (Paterson \& Thorne 1995). A similar rate $\left(4.38 \mu \mathrm{mol}\right.$ individual $\left.{ }^{-1} \mathrm{~h}^{-1}\right)$ was measured for Callianassa japonica, which accounted for only $12 \%$ of total burrow $\mathrm{O}_{2}$ consumption, with the remaining $88 \%$ (33.13 $\mu \mathrm{mol}$ burrow $\left.^{-1} \mathrm{~h}^{-1}\right)$ being consumed within the burrow walls and surrounding sediment (Koike \& Mukai 1983). Using Paterson \& Thorne's (1995) respiration rate, T. australiensis would have accounted for $25 \%$ of individual burrow $\mathrm{O}_{2}$ consumption in this study, with the remaining $75 \%\left(28 \mu \mathrm{mol} \mathrm{O}_{2}\right.$ burrow $^{-1} \mathrm{~h}^{-1}$ ) consumed by oxidation reactions, microorganisms and possibly other infaunal species associated with the burrow. Reactive and respiratory processes associated with $T$. australiensis burrows (other than T. australiensis respiration) accounted for approximately $37 \%$ of total sediment oxygen demand in the control sediments.

\section{Irrigation}

Sediment porewater exchange/irrigation calculated using Cs dilution over time gave a mean hourly control sediment rate of $15.3 \pm 4.3 \mathrm{l} \mathrm{m}^{-2} \mathrm{~h}^{-1}$, which was over 5 times the mean rate calculated for the treatment sediments $\left(2.6 \pm 1.2 \mathrm{l} \mathrm{m}^{-2} \mathrm{~h}^{-1}\right)$. The mean treatment sediment rate is attributed to passive diffusion into the sediments and the possible irrigation effects of meiofauna capable of increasing solute transport by 1.5 to 3.1 times that of diffusion (Rysgaard et al. 2000). In order to approximate rates attributable to the effects of Trypaea australiensis, the treatment mean hourly rate was subtracted from the control mean hourly rate to give $10.8 \mathrm{l} \mathrm{m}^{-2} \mathrm{~h}^{-1}$. This rate in turn was used to estimate flow volumes through T. australiensis burrows. However, such an estimation does not account for the recycling of Cs through the burrow respiratory loop and back to the chamber (resulting in under-estimation), and assumes that the mean difference in exchange rates between the treatment and control sediments is due to burrow irrigation only. Also, Cs is adsorbed onto sediment particles (Townsend 1998), and due to the increased sediment surface area that burrows provide, Cs adsorption may have been enhanced in the control incubations, causing an overestimation of transport rates. However, a degree of mutual cancellation may occur between these 2 factors.

Each control chamber was placed to capture 2 burrows. Dividing the difference between the mean treatment and control exchange rates $\left(0.911 \mathrm{l} \mathrm{chamber}^{-1}\right.$ $\mathrm{h}^{-1}$ ) by 2 approximated the individual Trypaea australiensis burrow irrigation rate $\left(0.456 \mathrm{l} \mathrm{burrow}^{-1} \mathrm{~h}^{-1}\right)$. This calculated hourly rate is near the upper range of rates $\left(0.139\right.$ to $\left.0.480 \mathrm{l} \mathrm{h}^{-1}\right)$ reported for other thalassinideans (Koike \& Mukai 1983, Colin et al. 1986, Nickell 1992, Foster \& Graf 1995, Astall et al. 1997). However, the rate for $T$. australiensis may be a significant underestimation, since Cs recycling through the respiratory loop has been ignored. Lower burrow irrigation rates were expected, as T. australiensis tolerates anoxic conditions (Paterson \& Thorne 1993, 1995) and has a predominantly detrital feeding mode (Kerr 2001). However, whilst other thalassinideans cease active burrow irrigation during hypoxic conditions to conserve energy and $\mathrm{O}_{2}$, T. australiensis may continue irrigation throughout periods of low $\mathrm{O}_{2}$ concentrations, albeit at a slower rate, and can be stimulated to a faster rate of irrigation when higher concentrations of $\mathrm{O}_{2}$ are detected (Paterson \& Thorne 1995). Increased irrigation activity by $T$. australiensis, correlating with rising water levels, was also observed by Kerr (2001). Our study confirmed this relationship, as a distinct pattern of increased mean irrigation rates corresponding to the high tide was observed throughout the $24 \mathrm{~h}$ control incubation (Fig. 3b). The stimulus for this behaviour is most likely distinct from or additional to the detection of increased $\mathrm{O}_{2}$ concentrations (the chambers being isolated from the main water column) and the increased irrigation response is possibly triggered by changes in water pressure.

The higher than expected Trypaea australiensis burrow irrigation rates may be characteristic of this species, or be affected by other contributing factors, such as the incorporation of a full $24 \mathrm{~h}$ in situ tidal regime during the study incubations. Laboratory experiments which do not incorporate significant water-level change may produce a 'steady state' reduced irrigation rate, noted during low tide in this study (less than half that of the high-tide rates). The benthic chambers incorporated a horizontal flow stirring system designed to closely resemble in situ linear current movement over the sediment (Webb \& Eyre in press). 2D water flow, 
over mound/funnel structures like those constructed by the burrowing activities of $T$. australiensis, enhances passive irrigation of burrows in the absence of active infauna pumping (Vogel \& Bretz 1972, Allanson et al. 1992, Heron \& Ridd 2001). As such, the burrow irrigation rates derived during this study may have combined a realistic capture of the pumping habits of the animals and the incorporation of passive physical ventilation induced by $2 \mathrm{D}$ water flow.

\section{Sediment oxygen profiles}

A main feature of the sediment $\mathrm{O}_{2}$ profiles was the far larger degree of variation measured in the control sediments (mean \% CV of 66 and 40 for the light and dark profiles respectively) over the treatment sediments (mean \% CV of 17 and 15 for the light and dark profiles respectively) and the deeper penetration of $\mathrm{O}_{2}$ into the control profiles. The shallow and uniform profiles measured in the treatment sediment matrix, and the linear $\left(\mathrm{r}^{2}\right.$ values ranged from 0.94 to 0.95$)$ decrease of $\mathrm{O}_{2}$ concentrations into the sediments and water column indicate that diffusion is the principal $\mathrm{O}_{2}$ transport mechanism in the absence of Trypaea australiensis. The greater variability and deeper $\mathrm{O}_{2}$ penetration measured in the control sediments may have resulted from higher irrigation rates and deeper sediment flushing due to burrow irrigation affecting surrounding sediments (Aller 1988). The higher degree of variation in the control profiles is also consistent with irrigation enhancement pertaining to biological influences rather than diffusion. The higher mean light $\mathrm{O}_{2}$ concentration (approximately 47\%) in the upper treatment sediments corresponded to the 2-fold greater concentrations of chl a measured in these sediments, with the upper $1 \mathrm{~mm}$ being $\mathrm{O}_{2}$-saturated $(490 \mu \mathrm{mol})$ in comparison to the control $(290 \mu \mathrm{mol})$.

\section{Nutrient flux}

Net and dark $\mathrm{N}_{2}$ effluxes were significantly different ( $p<0.001$ ) between the control and treatment sediments. Net $\mathrm{N}_{2}$ efflux in the control sediments (4925 \pm $1110 \mu \mathrm{mol} \mathrm{m} \mathrm{m}^{-2} \mathrm{~d}^{-1}$ ) was over 4 times greater than the treatments $\left(1194 \pm 517 \mu \mathrm{mol} \mathrm{m} \mathrm{m}^{-2} \mathrm{~d}^{-1}\right)$, and the control dark $\mathrm{N}_{2}$ efflux was more than 7 times greater than the treatments. Using Kenway's (1981) average Trypaea australiensis burrow dimensions, the 2 burrows per chamber in the control incubation would increase the reactive sediment surface area of each chamber by 76 to $108 \%$. The 4 -fold increase in net $\mathrm{N}_{2}$ efflux in the control sediments indicates that the increase in reactive sediment area was not solely responsible for the increased denitrification rates. Other studies (e.g. Aller 1988, Hansen \& Kristensen 1998, Kristensen \& Hansen 1999) have also found that macrofauna not only increase surface area, but also enhance sediment reactivity and increase the efficiency of solute mass transfer between the water column and sediments. Our study indicates that the presence of $T$. australiensis was responsible for approximately $76 \%$ of net $\mathrm{N}_{2}$ efflux in the study site sediments, comparing well with other studies, where macrofauna was responsible for $66 \%$ (Kristensen et al. 1991) and 52\% (Kristensen et al. 1985) of total sediment denitrification.

Stimulation of denitrification is linked to the increased supply of ammonium in macrofauna burrows due to animal excretion, organic matter accumulation, and greater nitrogen mineralisation rates enhanced by increased microbial activity and biomass (Henriksen et al. 1983, Vetter \& Hoppkinson 1985, Lillebo et al. 1999, Lavrentyev et al. 2000). Organic matter content in the upper control sediments was $13 \%$ greater than the treatment sediments, and Kerr (2001) found Trypaea australiensis burrow linings and faecal pellets to be up to 30 times richer in organic carbon in comparison to bulk sediments. The sediments inhabited by $T$. australiensis showed a net $\mathrm{NH}_{4}{ }^{+}$efflux of $969 \pm 846 \mu \mathrm{mol}$ $\mathrm{m}^{-2} \mathrm{~d}^{-1}$ compared to a net uptake of $\mathrm{NH}_{4}^{+}(680 \pm$ $556 \mu \mathrm{mol} \mathrm{m}{ }^{-2} \mathrm{~d}^{-1}$ ) in the treatment sediments. The net efflux of $\mathrm{NH}_{4}^{+}$in the control sediments occurred concurrently with the higher denitrification rates, suggesting that the production and supply of $\mathrm{NH}_{4}^{+}$ out-stripped coupled nitrification-denitrification. The treatment sediment net $\mathrm{NH}_{4}{ }^{+}$uptake corresponded to comparatively large net $\mathrm{NO}_{2}^{-}$and $\mathrm{NO}_{3}{ }^{-}$effluxes, indicating adequate oxidation of $\mathrm{NH}_{4}{ }^{+}$but decoupled nitrification-denitrification. Such decoupling may be a direct result of the comparative lack of oxic/anoxic niches (macrofauna burrows linings, faecal pellets, organic particles) in the treatment sediments.

In the control sediments, $\mathrm{NO}_{3}^{-}$and $\mathrm{NO}_{2}^{-}$concentrations showed a small net efflux $\left(69 \mu \mathrm{mol} \mathrm{m} \mathrm{m}^{-2} \mathrm{~d}^{-1}\right)$ and uptake $\left(7.2 \mu \mathrm{mol} \mathrm{m} \mathrm{m}^{-2} \mathrm{~d}^{-1}\right)$ respectively. These minor fluxes are concurrent with the control's higher denitrification rates and also suggest tight coupling between nitrification and denitrification. The higher net $\mathrm{NO}_{3}^{-}$ and $\mathrm{NO}_{2}^{-}$efflux measured in the treatment sediments (192 $\mu \mathrm{mol} \mathrm{m} \mathrm{m}^{-2} \mathrm{~d}^{-1}$ and $59.8 \mu \mathrm{mol} \mathrm{m} \mathrm{m}^{-2} \mathrm{~d}^{-1}$ respectively) and increased sediment $\mathrm{O}_{2}$ concentrations corresponded with other studies, where nitrification was stimulated by increased oxygen concentrations in the upper sediment layers, and conversely denitrification was suppressed by elevated oxygen concentrations (Joye \& Paerl 1994, Jørgensen 1996, Malcolm \& Sivyer 1997).

$\mathrm{NH}_{4}{ }^{+}$is preferentially consumed by microalgae during illumination (Valiela 1995), and the similar decrease in water column $\mathrm{NH}_{4}{ }^{+}$concentrations in both 
sediments from 06:00 h (dawn) until 15:00 h (late afternoon) suggests that autotrophic consumption by microphytobenthos was the main $\mathrm{NH}_{4}{ }^{+}$flux mediator during the illuminated period. The mean net efflux of $\mathrm{NH}_{4}{ }^{+}$in the control sediments $\left(969 \mu \mathrm{mol} \mathrm{m}^{-2} \mathrm{~d}^{-1}\right)$ indicates that the presence of Trypaea australiensis represents a significant supply of $\mathrm{NH}_{4}{ }^{+}$to the water column and as such, probably stimulates autotrophic productivity.

The uptake of $\mathrm{PO}_{4}{ }^{3-}$ during illumination in both sediments was probably due to utilisation by microphytobenthos, as assimilation by microalgae is considered a major $\mathrm{PO}_{4}{ }^{3-}$ sediment-water column flux mediator (Sundback et al. 1991). Increased oxidation of sediments associated with bioturbation has been shown to reduce $\mathrm{PO}_{4}{ }^{3-}$ efflux in comparison to defaunated sediments (Tuominen et al. 1999). However, the mean net phosphate $\left(\mathrm{PO}_{4}{ }^{3-}\right)$ flux showed a net uptake in the treatment sediments and a net efflux in the control sediments, which had deeper $\mathrm{O}_{2}$ penetration and 5 -fold greater irrigation rates. The tolerance of Trypaea australiensis to low $\mathrm{O}_{2}$ concentrations within their burrows (Paterson \& Thorne 1995) may have stimulated localised anoxic release of $\mathrm{PO}_{4}{ }^{3-}$ (Sayers et al. 1973, Gunatilaka 1982, Carlton \& Wetzel 1988) in their burrow linings and this, combined with $T$. australiensis excretion, possibly resulted in the net efflux of $\mathrm{PO}_{4}{ }^{3-}$ in the control sediments. As such, the presence of $T$. australiensis also represents a net source of $\mathrm{PO}_{4}{ }^{3-}$ to the water column, which may contribute to primary productivity.

\section{Management implications}

In eastern Australia, coastal engineering, stabilisation and deepening of lower estuary passages for navigation, and the reclamation of intertidal shallows has resulted in significant habitat loss for Trypaea australiensis over the last 200 yr. Additionally, the harvesting of this species as bait for both commercial and recreational fishing is unmonitored and a significant reduction in numbers on accessible sand flats within Moreton Bay, Queensland, was recorded as early as 1961 (Hailstone \& Stephenson 1961). This study suggests that $T$. australiensis has a significant influence over sediment biogeochemistry, and its potential role in nitrogen removal is particularly important considering the increasing trend of disturbance and nutrient enrichment in east Australian estuaries. As such, habitat destruction and unmanaged harvesting require further investigation, as it is likely that a reduction in system nutrient removal efficiency occurs concurrently with impacts on a given $T$. australiensis population.

\section{LITERATURE CITED}

Ahern B (2001) The effect of ray wallow formation on an intertidal meiofauna community in the Brunswick Estuary, northern NSW. School of Environmental Science and Management, Southern Cross University, Lismore, NSW

Allanson BR, Skinner D, Imberger J (1992) Flow in prawn burrows. Estuar Coast Shelf Sci 35:253-266

Aller RC (1982) The effects of macrobenthos on chemical properties of marine sediment and overlaying water. In: McCall PL, Jeresz MJS (eds) Animal-sediment relations. Plenum Press, New York, p 53-102

Aller RC (1988) Benthic fauna and biogeochemical processes in marine sediments: the role of burrow structures. In: Blackburn TH, Sørensen J (eds) Nitrogen cycling in coastal marine environments. John Wiley \& Sons, New York, p 301-330

Almgren T, Dryssen D, Fonselius S (1983) Determination of alkalinity and total carbonate. In: Grasshoff K, Ehrnhardt M, Kremling K (eds) Methods of seawater analysis. Verlag Chemie, Weinheim, p 99-123

Astall CM, Taylor AC, Atkinson RJA (1997) Behavioral and physiological implications of a burrow-dwelling lifestyle for two species of upogebiid mud-shrimp (Crustacea: Thalassinidea). Estuar Coast Shelf Sci 44:155-168

Banta GT, Holmer M, Jensen MH, Kristensen E (1999) Effects of two polychaete worms, Nereis diversicolor and Arenicola marina, on aerobic and anaerobic decomposition in a sandy marine sediment. Aquat Microb Ecol 19:189-204

Berelson WM, Townsend T, Heggie D, Ford P, Longmore A, Skyring G, Kilgore T, Nicholson G (1999) Modelling bioirrigation rates in the sediments of Port Phillip Bay. J Mar Freshw Res 50:573-579

Bird FL, Ford PW, Hancock G J (1999) Effect of burrowing macrobenthos on the flux of dissolved substances across the water-sediment interface. Mar Freshw Res 50:523-532

Botto F, Iribarne O (2000) Contrasting effects of two burrowing crabs (Chasmagnathus granulata and Uca uruguayensis) on sediment composition and transport in estuarine environments. Estuar Coast Shelf Sci 51:141-151

Branch GM, Pringle A (1987) The impact of the sand prawn Callianassa kraussi (Stebbing) on sediment turnover and on bacteria, meiofauna and benthic microflora. J Exp Mar Biol Ecol 107:219-235

Carlton RG, Wetzel RG (1988) Phosphorus flux from lake sediments: effect of epipelic algal oxygen production. Limnol Oceanogr 33:562-570

Clavero V, Fernandez JA, Niell FX (1992) Bioturbation by Neris sp. and its effects on the phosphate flux across the sediment-water interface in the Palmones River Estuary. Hydrobiologia 235/236:387-392

Colin PL, Suchanek TH, McMurtry G (1986) Water pumping and particulate resuspension by callianassids (Crustacea: Thalassinidea) at Enewetak and Bikini Atolls, Marshall Islands. Bull Mar Sci 38:19-24

Davis MW, Lee H (1983) Recolonization of sedimentassociated microalgae and effects of estuarine infauna on microalgal production. Mar Ecol Prog Ser 11:227-232

Dittman S (1996) Effects of macrobenthic burrows on infaunal communities in tropical tidal flats. Mar Ecol Prog Ser 134: $119-130$

Eaton AD, Clesceri LS, Greenberg AE (1995) Standard methods for the examination of water. American Public Health Association, Washington, DC

Eyre B (2000) Regional evaluation of nutrient transformations and phytoplankton growth in nine river-dominated subtropical east Australian estuaries. Mar Ecol Prog Ser 205: 61-83 
Eyre B, Ferguson AJP (2002) Comparison of carbon production and decomposition, benthic nutrient fluxes and denitrification in seagrass, phytoplankton, benthic microalgal and macroalgal-dominated warm temperate Australian lagoons. Mar Ecol Prog Ser 229:43-59

Eyre B, Ferguson A, Gay J (1997) Ecosystem response to nutrient loading - two northern NSW estuarine examples. Coastal Nutrient Workshop Papers. Australian Water and Waste Water Association, Brisbane, p 100-103

Eyre B, Rysgaard S, Dalsgaard T, Christensen PB (2002) Comparison of isotope pairing and $\mathrm{N}_{2}$ :Ar methods for measuring sediment denitrification - assumptions, modifications and implications. Estuaries 25:1077-1087

Ferguson AJP (2001) Nutrient cycling in shallow sub-tropical estuaries, northern New South Wales, Australia. PhD thesis, School of Environmental Science and Management, Southern Cross University, Lismore, NSW

Findlay RH, Trexler MB, Guckert JB, White DC (1990) Laboratory study of disturbance in marine sediments: response of a microbial community. Mar Ecol Prog Ser 62:121-133

Forster S, Graf G (1995) Impact of irrigation on oxygen flux into sediment: intermittent pumping by Callianassa subterranea and 'piston pumping' by Lanice conchilega. Mar Biol 123:335-346

Gilbert F, Bonin P Stora G (1995) Effects of bioturbation on denitrification in a marine sediment from the west Mediterranean littoral. Hydrobiologia 304:49-58

Gunatilaka A (1982) Phosphate adsorption kinetics of resuspended sediments in a shallow lake, Neusiedlersee, Austria. Hydrobiologia 91:293-298

Hailstone TS, Stephenson W (1961) The biology of Callianassa (Trypaea) australiensis Dana 1852 (Crustacea, Thalassinidea). Department of Zoology, University of Queensland, Brisbane, p 257-285

Hansen K, Kristensen E (1998) The impact of polychaete Nereis diversicolor and enrichment with macroalgal (Chaetomorpha linum) detritus on benthic metabolism and nutrient dynamics in organic poor and organic rich sediment. J Exp Mar Biol Ecol 231:201-223

Harris G, Batley B, Jernakoff P, Newell B and 7 others (1996) Port Phillip Bay Environmental Study Final Report. CSIRO, Canberra

Henriksen K, Kemp WM (1988) Nitrification in estuaries and coastal marine sediments. In: Blackburn TH, Sørensen J (eds) Nitrogen cycling in coastal marine environments. John Wiley \& Sons, New York p 207-240

Henriksen K, Rasmussen MB, Jensen A (1983) Effect of bioturbation of microbial nitrogen transformations in the sediment and fluxes of ammonium and nitrate to the overlaying water. Ecol Bull 35:193-205

Heron SF, Ridd PV (2001) The use of computational fluid dynamics in predicting the tidal flushing of animal burrows. Estuar Coast Shelf Sci 52:411-421

Jickells TD, Rae JE (1997) Biogeochemistry of intertidal sediments. In: Jickells TD, Rae JE (eds) Biogeochemistry of intertidal sediments. Cambridge University Press, Cambridge, p 1-15

Jørgensen BB (1996) Material flux in the sediment. In: Jørgensen BB, Richardson K (eds) Eutrophication in coastal marine ecosystems - coastal and estuarine studies. American Geophysical Union, Washington, DC, p 115-135

Joye SB, Paerl HW (1994) Nitrogen cycling in microbial mats: rates and patterns of denitrification and nitrogen fixation. Mar Biol 119:285-295

Kenway MJ (1981) Biological studies of Callianassa australiensis (Dana). PhD thesis, James Cook University, Townsville, QLD
Kerr G (2001) Ecological aspects of Trypaea australiensis. $\mathrm{PhD}$ thesis, School of Resource Science and Management, Southern Cross University, Lismore, NSW

Kerr G, Corfield J (1998) Association between the ghost shrimp Trypaea australiensis Dana 1852 (Crustacea: Decapoda) and a small deposit-feeding bivalve Mysella vitrea Laserson 1956 (Mollusca: Leptonidae). Mar Freshw Res 49:801-806

Koike I, Mukai H (1983) Oxygen and inorganic nitrogen contents and fluxes in burrows of shrimps Callianassa japonica and Upogebia major. Mar Ecol Prog Ser 12: 185-190

Kristensen E (2000) Organic matter digenesis at the oxic/ anoxic interface in coastal marine sediments, with emphasis on the role of burrowing animals. Hydrobiologia 426: $1-24$

Kristensen K, Hansen K (1999) Transport of carbon dioxide and ammonium in bioturbated (Nereis diversicolor) coastal, marine sediments. Biogeochemistry 45:147-168

Kristensen E, Jensen MH, Andersen TK (1985) The impact of polychaete (Nereis virens Sars) burrows on nitrification and nitrate reduction in estuarine sediments. J Exp Mar Biol Ecol 85:75-91

Kristensen E, Jensen MH, Aller RC (1991) Direct measurement of dissolved inorganic nitrogen exchange and denitrification in individual polychaete (Nereis virens) burrows. J Mar Res 49:355-377

Lachat (1994) International methods list for the QuikChem automated ion analyser. Lachat Instruments, Milwaukee

Lavrentyev PJ, Gardner WS, Yang L (2000) Effect of the zebra mussel on nitrogen dynamics and the microbial community at the sediment-water interface. Aquat Microb Ecol 21:187-194

Lillebo AI, Flindt MR, Pardal MA, Marques JC (1999) The effect of macrofauna, meiofauna and microfauna on the degradation of Spartina maritima detritus from a salt marsh. Acta Oecol 20:249-258

Malcolm SJ, Sivyer DB (1997) Nutrient recycling in intertidal sediments. In: Jickells TD, Rae JE (eds) Biogeochemistry of intertidal sediments. Cambridge University Press, Cambridge, p 84-98

Mortimer RJG, Davey JT, Krom PG, Watson PG, Frickers PE, Clifton RJ (1999) The effect of macrofauna on porewater profiles and nutrient fluxes in the intertidal zone of the Humber Estuary. Estuar Coast Shelf Sci 48:683-699

Nickell LA (1992) Deep bioturbation in organically enriched marine sediments. PhD thesis, University of Central London

Nickell LA, Atkinson RJA (1995) Functional morphology of burrows and trophic modes of three thalassinidean shrimp species, and a new approach to the classification of thalassinidean burrow morphology. Mar Ecol Prog Ser 128: 181-197

Nixon SW (1995) Coastal marine eutrophication: a definition, social causes, and future concerns. Ophelia 41:199-220

Olson RJ (1981) Differential photoinhibition of marine nitrifying bacteria: a possible mechanism for the formation of the primary nitrite maximum. J Mar Res 39:227-238

Page HM, Dugan JE, Hubbard DM (1992) Comparative effects of infaunal bivalves on an epibenthic microalgal community. J Exp Mar Biol Ecol 157:247-262

Paterson BD, Thorne MJ (1993) The effect of oxygen tension on the swimmeret rate of Callianassa australiensis and C. arenosa (Crustacea, Decapoda, Thalassinidea). Mar Behav Physiol 24:15-24

Paterson BD, Thorne MJ (1995) Measurements of oxygen uptake, heart and gill bailer rates of the callianassid burrowing shrimp Trypaea australiensis Dana and its 
response to low oxygen tensions. J Exp Mar Biol Ecol 194: 39-52

Pelegri SP, Blackburn TH (1994) Bioturbation effects of the amphipod Corophium volutator on micro nitrogen transformations in marine sediments. Mar Biol 121:253-258

Pelegri SP, Blackburn TH (1995) Effect of bioturbation by Nereis sp., Mya arenaria and Cerastoderma sp. on nitrification and denitrification in estuarine sediments. Ophelia 42:289-299

Pelegri SP, Nielsen LP, Blackburn TH (1994) Denitrification in estuarine sediment stimulated by the irrigation activity of the amphipod Corophium volutator. Mar Ecol Prog Ser 105:285-290

Rysgaard S, Christensen PB, Sørensen MV, Funch P, Berg P (2000) Marine meiofauna, carbon and nitrogen mineralisation in sandy and soft sediments of Disko Bay, West Greenland. Aquat Microb Ecol 21:59-71

Santschi P, Hohener P, Benoit G, Buchholtz-ten B (1990) Chemical processes at the sediment-water interface. Mar Chem 30:269-315

Sayers JK, Harris RF, Amstrong DE (1973) Phosphate chemistry in lake sediments. J Environ Qual 2:1-14

Stumm W, Morgan JJ (1996) Aquatic chemistry: chemical equilibra and rates in natural waters. John Wiley \& Sons, New York

Sundback K, Enoksson V, Graneli W, Pettersson K (1991) Influence of sublittoral microphytobenthos on the oxygen

Editorial responsibility: Otto Kinne (Editor),

Oldendorf/Luhe, Germany and nutrient flux between sediment and water: laboratory continuous-flow study. Mar Ecol Prog Ser 74:263-279

Townsend T (1998) Numerical simulations of tracer loss from benthic chambers: an investigation of bio-irrigation rates and patterns in marine sediments. PhD thesis, University of Southern California, San Diego

Tuominen L, Makela K, Lehtonen KK, Haahti H, Hietanen S, Kuparinen J (1999) Nutrient fluxes, porewater profiles and denitrification in sediment influenced by algal sedimentation and bioturbation by Monoporeia affinis. Estuar Coast Shelf Sci 49:83-97

Underwood AJ (1997) Experiments in ecology - their logical design and interpretation using analysis of variance. Cambridge University Press, Cambridge

Valiela I (1995) Marine ecological processes. Springer-Verlag, New York

Vetter EF, Hopkinson CS Jr (1985) Influence of white shrimp (Penaeus setiferus) on benthic metabolism and nutrient flux in a coastal marine ecosystem: measurements in situ. Contrib Mar Sci 28:95-107

Vogel S, Bretz WI (1972) Interfacial organisms: passive ventilation in the velocity gradients near surfaces. Science 175 : $210-211$

Webb AP, Eyre B (in press) The effects of 2 benthic chamber stirring systems on the diffusive boundary layer, oxygen flux and passive flow through model macrofauna burrows. Estuaries

Submitted: September 2, 2002; Accepted: September 30, 2003 Proofs received from author(s): March 1, 2004 